EVIDENCE FOR TICAL UPWELL1NG ACROSS

\title{
EVIDENCE FOR TIDAL UPWELLING ACROSS THE SILL OF AMBON BAY
}

\author{
by \\ L. F. WENNO ${ }^{1)}$ and JAMES JAY ANDERSON ${ }^{2)}$
}

\begin{abstract}
Temperature observations across the sill of Ambon Bay in August 1982 and a model suggest that during the upwelling season of the south east monsoon tidal upwelling on the flood tide can suck thermocline water up the outer slope of the sill from a depth of 50 to $80 \mathrm{~m}$. The water enters over the $10 \mathrm{~m}$ sill and replaces the bottom water in the inner part of Ambon Bay.
\end{abstract}

ABSTRAK

Pengamatan-pengamatan suhu pada ambang Teluk Ambon dalam bulan Agustus 1982 dan sebuah model yang dibuat memberi kesan bahwa selama musim upwelling dalam monsun tenggara, upwelling pasang-surut yang terjadi pada waktu air pasang dapat menghisap air di lapisan termoklin dari kedalaman 50 sampai $80 \mathrm{~m}$ ke atas sampai lereng luar dari ambang. Air Teluk Ambon bagian luar ini masuk melewati ambang yang dalamnya $10 \mathrm{~m}$ dan menggantikan air dasar perairan di Teluk Ambon bagian dalam,

\section{INTRODUCTION}

Ambon Bay in Indonesia contains an enclosed inner bay separated from an outer bay by a shallow $10 \mathrm{~m}$ sill (Figure 1). The exchange of water across the sill affects the inner bay conditions and keeps the inner bay from becoming anoxic. ANDERSON \& SAPULETTE (1981) have demonstrated that the most active renewal of inner bay water takes place during the southeast monsoon when upwelling in the Banda Sea (WYRTKI 1961) causes the thermocline in the outer bay to raise from 150 to $75 \mathrm{~m}$ depth. Water from the thermocline definitely enters the inner bay indicating that the outer bay thermocline is pulled up onto the sill, a displacement of some $60 \mathrm{~m}$.

In this article we demonstrate that the movement onto the sill occurs on the flood tide and present a model to estimate the maximum depth from which water can be pulled onto the sill by tidal upwelling.

1) Ambon Research Station, National Institute of Oceanology, Ambon, Indonesia.

$\left.{ }^{2}\right)$ Fisheries Research Institute, University of Washington, Seattle, Washington, U.S.A. 

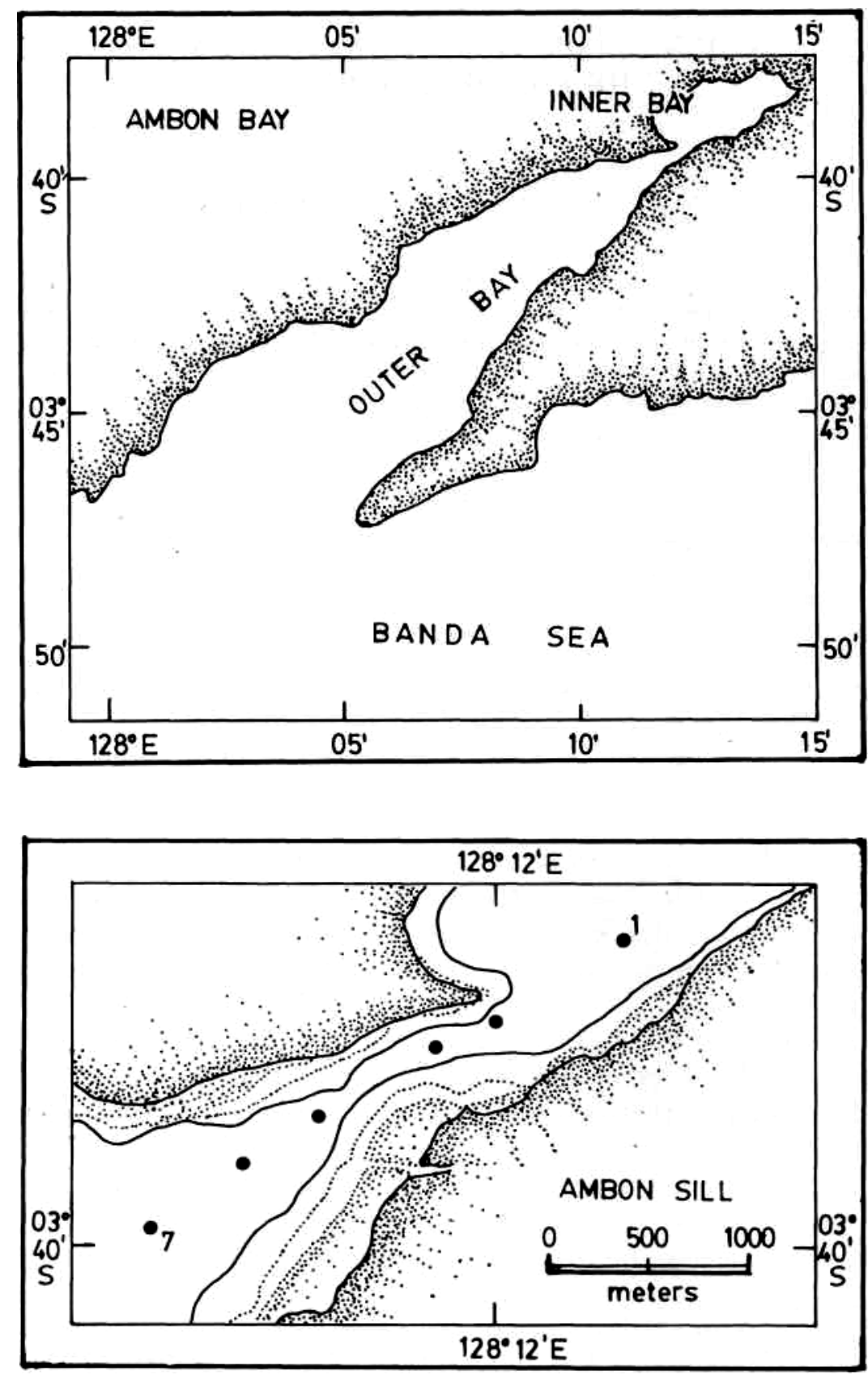

Figure 1. Ambon Bay showing detail of sill region and station locations. 


\section{METHODS}

Temperature profiles across the sill of Ambon Bay were measured on flood and ebb tides on 13 August 1982 using a Mondedoro-Whitney portable conductivity and temperature instrument model CTU-4. This provided accuracy on the order of $0.05^{\circ} \mathrm{C}$. Profiles were made at seven stations with readings taken at $1 \mathrm{~m}$ depth intervals (Figure 1 ).

\section{RESULTS}

The temperature profiles were made near the maximum currents of the ebb and flood tides. Measurements of surface currents across the sill using drogues indicated tidal speeds of 1 to $2 \mathrm{~m} / \mathrm{s}$. The tidal amplitude was $1.3 \mathrm{~m}$.

Sea surface temperature is low in August $\left(24^{\circ} \mathrm{C}\right.$ ) (ANDERSON \& SAPULETTE 1981) and the thermocline depth in the outer bay is shallow at about $75 \mathrm{~m}$. In February the surface temperature is warm $\left(30^{\circ} \mathrm{C}\right)$ and the thermocline depth is deep at about $150 \mathrm{~m}$. The two crossings of the sill indicated the temperature distribution changes much between the ebb and flood tides. At the outer slope of the sill the $24^{\circ} \mathrm{C}$ isotherm rises and falls between the flood and ebb tides. On the flood tide the isotherm was about $10 \mathrm{~m}$ deep and on the ebb tide it dropped to below $50 \mathrm{~m}$. In the outer bay the $24^{\circ} \mathrm{C}$ isotherm is between 50 and $75 \mathrm{~m}$ deep in August (LON unpublished report). Bottom water temperature in the inner bay does not fluctuate with the tides and was $23.5^{\circ} \mathrm{C}$ (Figure 2).

These observations suggest that in August, on the flood tide, a tidal upwelling mechanism sucks water onto the sill and into the inner bay. A model postulating the dynamics of the process, which estimates the maximum depth from which water can be drawn onto the sill, can be developed from the work of THOMPSON \& GOLDING (1981).

MODEL

THOMPSON \& GOLDING (1981) observed that the occurrence of cooler water at the edge of a coral reef in Cook's Passage on the Great Barrier Reef might be explained through a tidal upwelling mechanism. They postulated that the tidal pressure gradient can suck water up the reef slope and presented a model to calculate the depth to which the effect can reach. The sill separating the inner and outer parts of Ambon Bay is much like a reef and so we apply the model to determine the original depth in the outer bay of the water that is brought over the sill to replace the inner bay bottom water. 


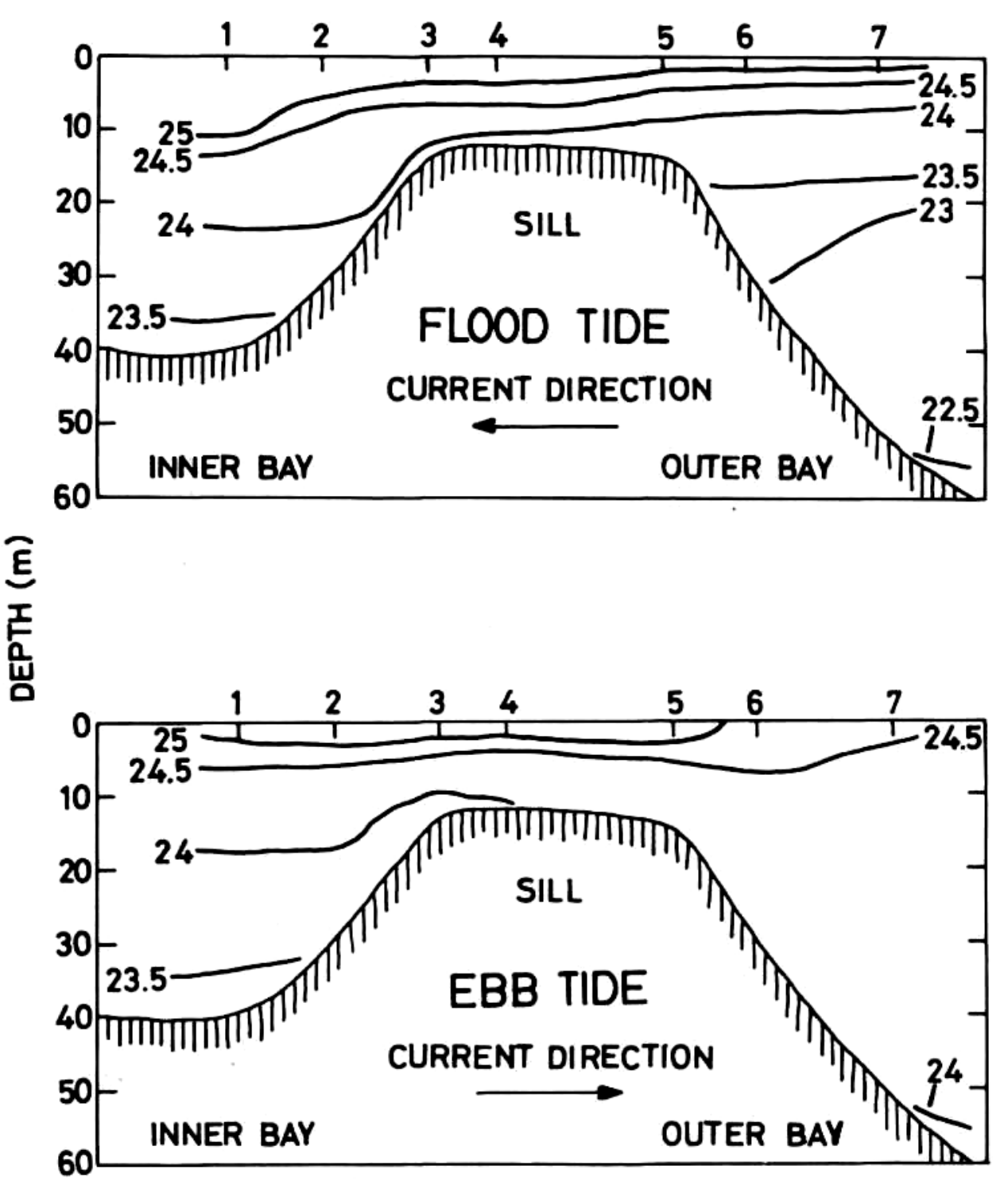

Figure 2. Temperature distributions across the sill on Flood and Ebb tides. Temperature in degrees $C$. 


\section{EVIDENCE FOR TICAL UPWELLING ACROSS}

In the model maximum depth of tidal suction is the point where the tidal wave moving onto the sill is equal to in speed and in the opposite direction to the corresponding internal wave. To determine this depth, first the tidal speed is determined as a function of sill geometry and the surface current speed over the sill. Next, the speed of the fastest internal wave is calculated as a function of depth and stratification. The critical depth, where the two speeds are equal, is determined by plotting the speeds of both waves with depth.

The sill is flat across its main channel and abruptly plunges at points connecting to the inner and outer bays (Figure 2). The tidal speed in terms of the sill cross section and depth is defined

$$
\mathrm{U}=\mathrm{U}^{\circ} \mathrm{L}^{\circ} \mathrm{H}^{\circ} / \mathrm{LH}
$$

where $\mathrm{U}^{\circ}, \mathrm{L}^{\circ}$, and $\mathrm{H}^{\circ}$ are the tidal current, sill width and sill depth. The variables $\mathrm{U}, \mathrm{L}$ and $\mathrm{H}$ are the same measures at some distance down slope from the sill edge where positive $\mathrm{x}$ is directed towards the outer bay and $x=0$ at the sill edge. On the flood tide we take the sill edge as the outer sill slope change and then the sill width and depth outward from this point can be defined by the relationships

$$
\begin{aligned}
& H=a x+H^{\circ} \\
& L=L^{\circ}-2 b x
\end{aligned}
$$

where $\mathrm{a}$ and $\mathrm{b}$ are the bottom slope and channel angle outward from the point $\mathrm{x}=0$. For the ebb tide the point $\mathrm{x}=0$ is taken as the inner sill slope change and a and b correspond to the slope and channel angle into the inner bay. Values for $\mathrm{a}, \mathrm{b}, \mathrm{L}^{\circ}$ and $\mathrm{H}^{\circ}$ on ebb and flood tides are given in Table 1. The tidal current speed at a distance $\mathrm{x}$ is defined

$$
\mathrm{U}=\mathrm{U}^{\circ} \mathrm{L}^{\circ} \mathrm{H}^{\circ} /\left((\mathrm{l}+2 \mathrm{bx})\left(\mathrm{ax}+\mathrm{H}^{\circ}\right)\right)
$$

THOMSON \& GolDING (1981) give an approximation for the fastest internal wave speed $\mathrm{C}$ by the equation

$$
\mathrm{NHm} / \mathrm{C}+\tan (\mathrm{H} \mathrm{h} / \mathrm{C})=\mathrm{O}
$$

where $\mathrm{N}$ is the buoyancy frequency $\mathrm{N}^{2}=-\mathrm{g}(\mathrm{dp} / \mathrm{dz}) / \mathrm{p}, \mathrm{Hm}$ is the thickness of the mixed surface layer, and $h=a x-H m$ is the thickness of the underlying stratified layer. 


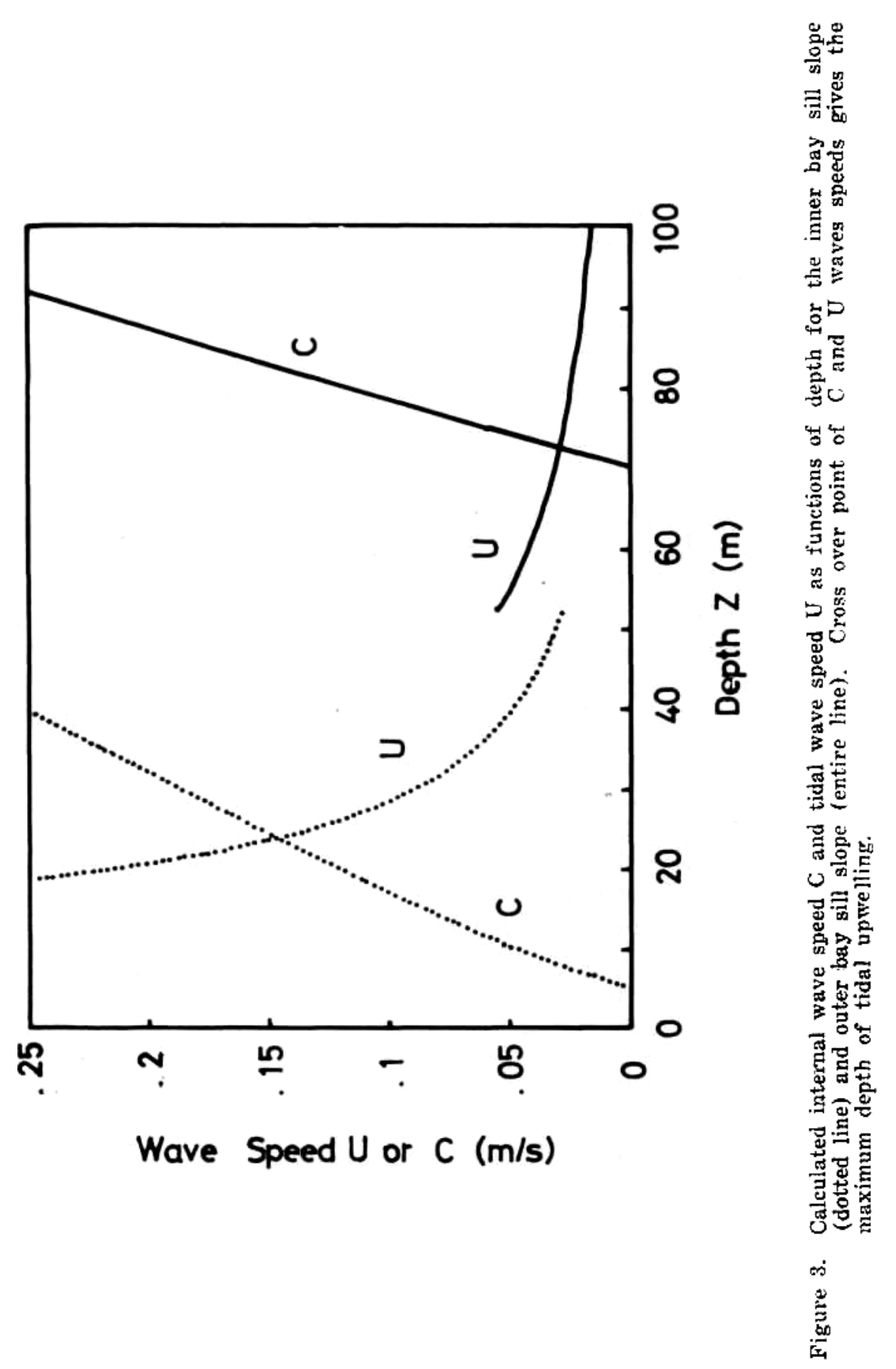


EVIDENCE FOR TICAL UPWELLING ACROSS

Table L. Equation parameters for inner and outer bay are sill slope gradient a, channel angle b, thickness of mixed layer $\mathrm{Hm}$, and buoyancy frequency $\mathrm{N}$.

\begin{tabular}{cccc}
\hline Parameters & Units & Inner Bay & Outer Bay \\
\hline $\mathbf{a}$ & & & \\
\hline $\mathbf{b}$ & $\mathrm{m} / \mathrm{m}$ & 0.04 & 0.06 \\
$\mathrm{Hm}$ & $\mathrm{m} / \mathrm{m}$ & 0.55 & 0.35 \\
$\mathrm{~N}$ & $\mathrm{~m}$ & 5 & 70 \\
& $\mathbf{1 / 8}$ & 0.02 & 0.02 \\
\hline
\end{tabular}

Using a sill tidal velocity of $U=1 \mathrm{~m} / \mathrm{a}$ and the parameters in Table 1 the tidal speeds and internal wave speeds are plotted as functions of depth $\mathrm{z}$ (Figure 3). The crossover points of $\mathrm{U}$ and $\mathrm{C}$ give the maximum depth of tidal suction and for the ebb tide, water from a depth of $24 \mathrm{~m}$ in the inner bay can be sucked onto the sill, while on the flood tide water from a depth of $73 \mathrm{~m}$ in the outer bay can be sucked onto the sill.

\section{DISCUSSION}

The model suggests that the thermocline water in the outer bay can indeed be brought over the sill to replace the inner bay bottom water. This conclusion is supported by the observed bottom water temperature in the inner bay, which at $23.5 \mathrm{C}$ must have originated in the outer bay thermocline, which at the time of observations was about 70 to $85 \mathrm{~m}$ in depth. The model also suggests that tidal suction on the ebb tide should not reach deep enough to remove the inner bay bottom water. This conclusion is supported by the rate of warming of the inner bay bottom water during the northwest monsoon. ANDERSON \& SAPULETTE (1981) have estimated that the vertical diffusion coefficient during the inner bay warming is on the order of $0.1 \mathrm{~m}^{2} / \mathrm{s}$. This is small and suggests bottom water mixing is by vertical diffusion and not advection.

We expect Ambon Bay is typical of many silled estuaries and suggest that tidal upwelling may be an important feature in providing new waters from depths well below the sill depth.

\section{ACKNOWLEDGEMENTS}

This research was supported under USAID Contract No. AID-49779100 to the University of Washington, and by the Indonesian Institute of Sciences. We wish to thank Dr. Aprilani Soegiarto, Director of the National Institute of Oceanology, Jakarta, and Mr. Atjep Suwartana, 


\section{F. WENNO \& JONES JAY ANDERSON}

Head of Ambon Station of the National Institute of Oceanology, for their support during this project.

\section{REFERENCES}

ANDERSON, J.J. and D. SAPUlETte 1981. Deep water renewal in Ambon Bay, Ambon, Indonesia. Proc. Fourth Int. Coral Reef Sympos., Manila, Philippines 1: 360 - 374.

Thompson, R.O.R.Y. and T.J. Golding 1981. Tidally induced "upwelling" in the Great Barrier Reef. J. Geophys. Res, 86: 6517-6521.

WYrtKi, K. 1961. Physical Oceanography of the southeast Asian waters. Naga Rep. 2: 1-195. 